\title{
Transconjunctival retinopexy with active external drainage of subretinal fluid: a prospective pilot study of eight consecutive cases
}

\author{
Retinopexia transconjuntival com drenagem externa dofluidosub-retiniano: \\ um estudo piloto prospectivo de oito casos consecutivos
}

\author{
Rubens Camargo Siqueira ${ }^{1}$ \\ Rodrigo Jorge $\mathbf{e}^{2}$ \\ Ingrid Ursula Scott ${ }^{3}$
}

Trabalho realizado no Department of Ophthalmology, Catanduva Medicine School, SP and Department of Ophthalmology. School of Medicine of Ribeirão Preto, University of São Paulo - USP - Ribeirão Preto (SP) Brazil.

${ }^{1}$ CERV - Retina and Vitreous Specialized Center of HORP - Eye Hospital of Rio Preto, São José do Rio Preto (SP) Brazil. Retina and Vitreous Section, Department of Ophthalmology, School of Medicine of Ribeirão Preto, University of São Paulo - USP - Ribeirão Preto (SP) - Brazil. ${ }^{2}$ Retina and Vitreous Section, Department of Ophthalmology, School of Medicine of Ribeirão Preto, University of São Paulo - USP - Ribeirão Preto (SP) - Brazil.

${ }^{3}$ Departments of Ophthalmology and Health Evaluation Sciences, Penn State College of Medicine - Hershey Pennsylvania - USA.

Correspondence to: Rubens Camargo Siqueira. Av. José Munia, 4500 - São José do Rio Preto (SP)

Zip Code 15090-500

E-mail: rubenssiqueira@terra.com.br

Recebido para publicação em 05.11.2006

Última versão recebida em 26.02.2007

Aprovação em 22.04.2007

The authors have no proprietary interests in any of the products cited in this paper.

\begin{tabular}{l} 
ABSTRACT \\
\hline Purpose: To describe an alternative surgical technique for the management \\
of retinal detachment with no or minimal proliferative vitreoretinopathy \\
(grade B) using transconjunctival retinopexy with active external drainage \\
of subretinal fluid. Methods: In a prospective, interventional study, eight \\
consecutive patients with retinal detachment with no or minimal pro- \\
liferative vitreoretinopathy (grade B) underwent transconjunctival reti- \\
nopexy with active external drainage of subretinal fluid. Transconjunctival \\
external drainage of subretinal fluid was achieved by using a 29 gauge \\
needle placed in the subretinal space under indirect ophthalmoscopic \\
monitoring. Active suction was performed (500 mmHg vacuum) using a \\
vitrectomy line coupled to the needle. After retinal reattachment, cryo- \\
therapy was applied to the scleral region corresponding to the area of the \\
retinal break(s). Results: In all cases there was retinal attachment at the \\
end of surgery. Retinal redetachment occurred in four pseudophakic \\
patients who then underwent pars plana vitrectomy. The four phakic \\
patients maintained retinal attachment during follow-up (13-20 months). \\
Conclusion: Transconjunctival retinopexy with active external drainage \\
of subretinal fluid represents a useful, faster, and cheaper alternative to \\
scleral buckling for retinal detachments with no or minimal proliferative \\
retinopathy in phakic patients and, unlike scleral buckling, is not associated \\
with induced myopia.
\end{tabular}

Keywords: Retina; Retinal detachment/surgey; Drainage/methods; Body fluids

\section{INTRODUCTION}

Although superior rhegmatogenous retinal detachments can be repaired surgically using nondrainage techniques, removal of subretinal fluid remains an important surgical step in retinal detachments with inferior breaks. Drainage of subretinal fluid has been reported to be the most hazardous step in retinal detachment surgery ${ }^{(1)}$. The most common complications of subretinal fluid drainage include subretinal hemorrhage, retinal incarceration, and retinal perforation ${ }^{(2-3)}$. Several external drainage techniques have been described ${ }^{(4-6)}$, such as using a suture needle and argon laser for scleral and choroidal perforation ${ }^{(2)}$. In 1985, McLeod described a technique for posterior transcleral drainage of subretinal fluid monitored by indirect ophthalmoscopy to drain posteriorly sequestrated subretinal fluid following vitrectomy ${ }^{(3)}$. Drainage monitoring was also described by Char- 
les, who used a 25-gauge needle and an automated system for external drainage, associated with conventional scleral buckling $^{(4)}$. In the current report, we describe a new technique of transconjunctival retinopexy with active external drainage of subretinal fluid.

\section{METHODS}

The study was approved by the Institutional Review Board of the University of São Paulo and written informed consent was obtained from all study participants. Eight consecutive patients with retinal detachment with minimal or no proliferative retinopathy (grade B) underwent transconjunctival retinopexy with active external drainage of subretinal fluid. Inclusion criteria for the study included:

1) Primary rhegmatogenous retinal detachment;

2) All retinal breaks located within 1 clock hour of the fundus; and

3) No or minimal proliferative vitreoretinopathy (grade B).

All patients were followed for a minimum of 10 months (1020 months). Preoperative data collected included age, gender, race, involved eye, previous ocular surgery or trauma, duration of symptoms, presenting best-corrected visual acuity, status of the macula (attached or detached), circumferential extent of retinal detachment (number of clock hours), location of retinal breaks (in the superior 4 clock hours [10 to 2 o' clock, inclusive]; temporally or nasally [2 to 4 o'clock or 8 to 10 o'clock, noninclusive]; or in the inferior 4 clock hours [ 4 to 8 o' clock, inclusive]), lens status (phakic, pseudophakic, aphakic).

\section{Surgical technique}

All patients underwent surgery by the same surgeon (RCS). Peribulbar anesthesia with $5 \mathrm{ml} 2 \%$ lidocaine and $5 \mathrm{ml} 0.5 \%$ bupivacaine was administered. The eye and surgical field were prepped with povidone-iodine and draped with a sterile drape. One drop $2 \%$ aqueous povidine was instilled into the fornix before surgery. Using indirect ophthalmoscopy, the drainage site was determined and marked on the sclera over the conjunctiva using bipolar cautery. A 29-gauge needle was coupled to the aspiration line (Figure 1) from the Accurus vitrectomy machine (Alcon, Fort Worth, Texas, USA). The distal $3 \mathrm{~mm}$ of the needle was bent and inserted through the conjunctiva and sclera at the point marked previously next to the biggest retinal elevation but non near the tear and the needle tip was visualized by indirect ophthalmoscopy as "flashing steel" in the subretinal space (Figure 2). Five hundred millimeters of mercury aspiration was employed to remove the subretinal fluid slowly under indirect ophthalmoscopic monitoring. During active aspiration, the needle tip was redirected in the subretinal space according to the level of subretinal fluid in order to avoid retinal perforation. As the retinal detachment became shallower, the aspiration was reduced by using the foot pedal control. The needle tip was withdrawn when the retina was in close proximity to the tip. Intravitreal injection of balanced salt solution (BSS, Alcon, Fort Worth, Texas, USA) was necessary in very extensive retinal detachments in order to avoid hypotony. After retinal reattachment, cryotherapy was applied to the scleral region that corresponded to the retinal break(s).

\section{Postoperative examinations}

Postoperative examinations were conducted on days 1,7 , and 14 and then months 1, 3, 6, and 12 after surgery. Each postoperative examination included measurement of best-corrected visual acuity, slit-lamp examination, applanation tonometry, and dilated fundus examination.

\section{RESULTS}

Clinical characteristics of the study population and study results are summarized in table 1 . The mean follow-up duration

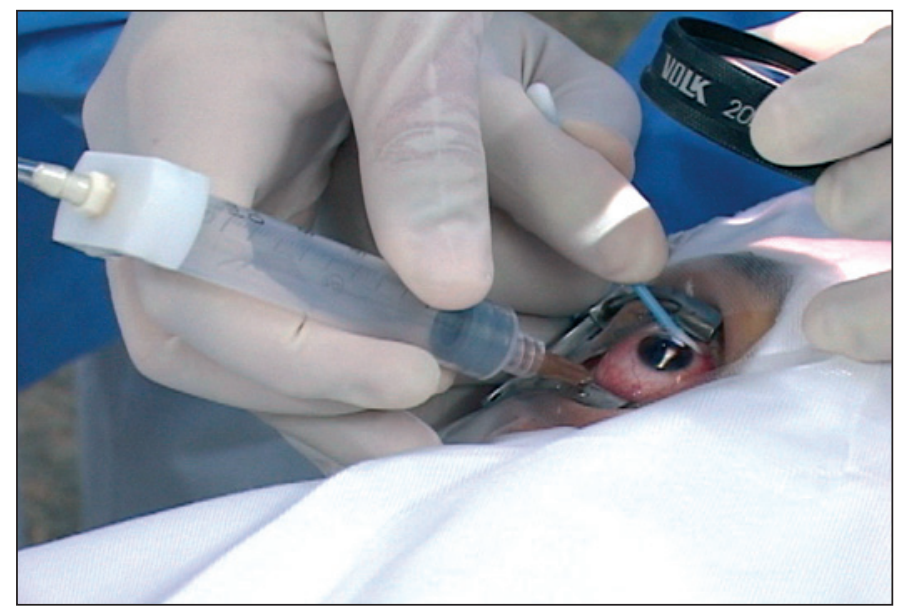

Figure 1 - Transconjuctival retinopexy. An external photograph showing monitoring of subretinal fluid drainage, after needle insertion through the sclera.

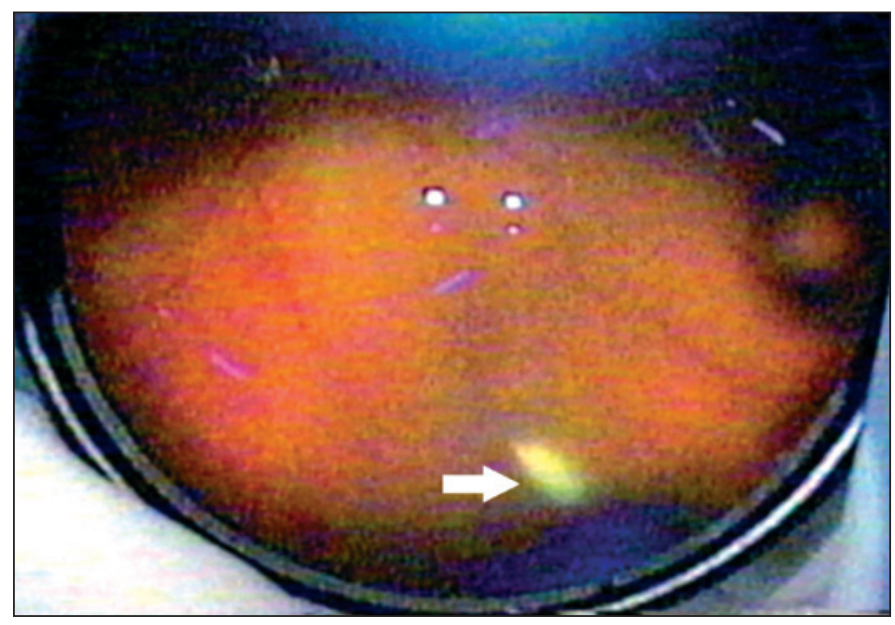

Figure 2 - Indirect ophthalmoscopic color fundus photograph showing the "flashing steel" image of the needle tip under the retina (white arrow) 


\begin{tabular}{|c|c|c|c|c|c|c|c|c|c|c|}
\hline Patient & Gender & Age & Eye & $\begin{array}{c}\text { Preop } \\
\text { VA }\end{array}$ & $\begin{array}{c}\text { Final } \\
\text { VA }\end{array}$ & $\begin{array}{c}\text { RD and } \\
\text { distribution of } \\
\text { breaks }\end{array}$ & $\begin{array}{l}\text { Recurrent } \\
\text { RD }\end{array}$ & $\begin{array}{l}\text { Compli- } \\
\text { cations }\end{array}$ & $\begin{array}{l}\text { Lens } \\
\text { status }\end{array}$ & Follow-up \\
\hline 1 & $\mathrm{~F}$ & 18 & Left & $\mathrm{HM}$ & CF $1 \mathrm{~m}$ & $\begin{array}{c}\text { Superior RD } \\
\text { (tear at } 12 \text { o'clock) } \\
\text { macula-off }\end{array}$ & yes & Inferior PVR & Phakic & 18 months \\
\hline 2 & $M$ & 27 & Left & $20 / 30$ & $20 / 60$ & $\begin{array}{c}\text { Inferior RD } \\
\text { (tear at } 6 \text { o'clock) } \\
\text { macula-on }\end{array}$ & yes & Inferior PVR & Pseudophakic & 10 months \\
\hline 3 & M & 52 & Left & $20 / 20$ & $20 / 60$ & $\begin{array}{c}\text { Temporal RD } \\
\text { macula-on }\end{array}$ & yes & $\begin{array}{l}\text { Subretinal } \\
\text { hemorrhage }\end{array}$ & Pseudophakic & 12 months \\
\hline 4 & $M$ & 39 & Left & $20 / 40$ & $20 / 20$ & $\begin{array}{c}\text { Inferior RD } \\
\text { (tear at } 7 \text { o'clock) } \\
\text { macula-on }\end{array}$ & no & no & Phakic & 20 months \\
\hline 5 & $\mathrm{~F}$ & 58 & Right & $20 / 60$ & $20 / 200$ & $\begin{array}{c}\text { Superior RD } \\
\text { (tear at } 11 \text { o'clock) } \\
\text { macula-off }\end{array}$ & yes & Inferior tear & Pseudophakic & 15 months \\
\hline 6 & $M$ & 19 & Right & $20 / 60$ & $20 / 20$ & $\begin{array}{c}\text { Inferior RD } \\
\text { (tear at } 3 \text { o'clock) } \\
\text { macula-off }\end{array}$ & no & no & Phakic & 16 months \\
\hline 7 & $M$ & 40 & Right & $20 / 200$ & $20 / 80$ & $\begin{array}{c}\text { Temporal RD } \\
\text { (tear at } 3 \text { o'clock) } \\
\text { macula-off }\end{array}$ & no & no & Phakic & 13 months \\
\hline 8 & $M$ & 52 & Right & $20 / 40$ & $20 / 20$ & $\begin{array}{c}\text { RD } \\
\text { (tear at } 10 \text { o'clock) } \\
\text { macula-on }\end{array}$ & no & no & Phakic & 14 months \\
\hline
\end{tabular}

was 15 months, a period considered sufficient for analysis of results, since proliferative vitreoretinopathy typically develops between 6 and 8 weeks after surgery. The average age of the patients was 60 years (range, 35-86 years).

In all cases, there was complete retinal attachment at the end of surgery. One patient developed a subretinal hemorrhage during drainage that resolved spontaneously within 4 weeks. Retinal redetachment occurred in four of eight patients (all four patients who developed recurrent retinal detachment were pseudophakic with inferior proliferative vitreoretinopathy) at a mean of 17 days (range, 7-40 days) after initial retinal detachment repair; these patients then underwent successful retinal detachment repair using a standard three-port pars plana vitrectomy technique. The four phakic patients maintained retinal attachment during follow-up (13-20 months). None of the patients developed elevated intraocular pressure during the follow-up period.

\section{DISCUSSION}

Various techniques of subretinal fluid drainage have been described using passive and active drainage with or without indirect ophthalmoscopic monitoring ${ }^{(3-4,7-11)}$. Passive needle drainage of subretinal fluid without monitoring is the most extensively used technique. Our technique consists of a transconjunctival approach with active external drainage of subretinal fluid under indirect ophthalmoscopic monitoring.

Scleral buckling requires partial or 360 degrees of conjunc- tival and Tenon's capsule reflection and rectus muscle isolation. Our technique does not require conjunctival, Tenon's or rectus muscle manipulation.

Ophthalmoscopic monitoring of subretinal fluid drainage was reported $^{(3)}$ and this technique consisted of external drainage of posteriorly-sequestrated subretinal fluid following vitrectomy and fluid/gas or fluid/silicone oil exchange, thereby avoiding the need to create a drainage retinotomy site. These authors emphasized the reduced risk of retinal incarceration and prolapse with ophthalmoscopic monitoring. However, monitoring of subretinal fluid drainage requires clear media for optimal visualization of the needle tip in the subretinal space. For this reason, scleral buckling may be more appropriate for patients with moderate or advanced cataract.

Subretinal hemorrhage is a potential complication of subretinal fluid drainage ${ }^{(5)}$. One patient in the current series developed this complication. Subretinal hemorrhage is less likely to occur during active monitored drainage because there is a sharp choroidal penetration with a very thin 29 -gauge needle and there is no choroidal congestion induced by prior cryotherapy. In addition, if there is bleeding into the subretinal space, the blood tends to be aspirated with the subretinal fluid while choroidal vascular thrombosis occurs ${ }^{(3)}$.

Hypotony is another potential complication of subretinal fluid drainage. To avoid this complication, some surgeons perform drainage with concomitant injection of vitreous substitutes $^{(3)}$ or tighten the scleral buckle prior to drainage ${ }^{(6)}$. In the current series, intravitreal injection of balanced salt solution 
was sometimes performed to restore intraocular pressure and avoid corneal folds, which may prevent good visualization of the posterior segment.

In the absence of severe vitreous traction on the retina, chorioretinal adhesion promoted by cryotherapy scars may be sufficient to maintain the retina attached without scleral indentation, as with pneumatic retinopexy ${ }^{(7)}$. The absence of scleral indentation avoids buckle-induced myopia.

All patients who developed recurrent retinal detachment were pseudophakic. The distinct category of pseudophakic retinal detachment compared with phakic retinal detachment has a higher prevalence of missed breaks (5\%-20\%), resulting from the smaller size and anterior location of breaks in these eyes as well as from the incomplete peripheral fundus view due to anterior or posterior capsule fibrosis, cortical remnants, small pupil, vitreous opacities, and optical aberrations at the intraocular lens rim $^{(8,12-14)}$. All phakic patients in the current series maintained retinal attachment during follow-up (13-20 months).

\section{CONCLUSION}

Transconjunctival retinopexy with active external drainage of subretinal fluid represents a useful alternative technique for retinal detachment repair in phakic patients with little proliferative vitreoretinopathy; this technique is quicker and cheaper compared with scleral buckling, and is not associated with induced myopia. Further studies are needed to determine the safety and efficacy of this new technique to repair phakic retinal detachments with no or minimal proliferative vitreoretinopathy (grade B).

\section{RESUMO}

Objetivo: Descrever uma técnica cirúrgica alternativa para o tratamento de descolamento da retina sem ou com mínima vitreorretinopatia proliferativa (grau B) usando uma retinopexia transconjuntival com drenagem externa do fluido subretiniano. Métodos: Prospectivo estudo intervencional, com oito pacientes consecutivos com descolamento da retina com nenhum ou mínima vitreorretinopatia proliferativa (grau B) que foram submetidos a retinopexia transconjuntival com drenagem externa ativa do fluido sub-retiniano. A drenagem externa transconjuntival do fluido sub-retiniano foi realizada com agulha calibre 29 colocada no espaço sub-retiniano e moni- torada pela oftalmoscopia binocular indireta. A sucção ativa foi realizada (vácuo de $500 \mathrm{mmHg}$ ) usando a linha de extração do vitreófago conectado a agulha. Após a colagem da retina, crioterapia foi aplicada na região escleral correspondente a área da(s) ruptura(s). Resultados: Em todos os casos a retina aplicou no final da cirurgia. O redescolamento da retina ocorreu em 4 pacientes pseudofácicos, que foram submetidos a seguir a vitrectomia pars plana. Os 4 pacientes fácicos mantiveram a retina aplicada durante o seguimento (13 a 20 meses). Conclusão: A retinopexia transconjuntival com drenagem externa ativa do fluido sub-retiniano representa alternativa útil, rápida e barata a cirurgia do descolamento da retina com implante escleral em pacientes com nenhuma ou mínima vitreorretinopatia proliferativa, fácicos e diferente do implante escleral não está associada a indução da miopia.

Descritores: Retina; Descolamento retiniano/cirurgia; Drenagem/métodos; Líquidos corporais

\section{REFERENCES}

1. Ferguson EC. Drainage of subretinal fluid in scleral bucklings. Int Ophthalmol Clin. 1962;2:181-205.

2. Bovino JA, Marcus DF, Nelsen PT. Argon laser choroidotomy for drainage of subretinal fluid. Arch Ophthalmol. 1985;103(3):443-4.

3. McLeod D. Monitored posterior transcleral drainage of subretinal fluid. $\mathrm{Br} \mathrm{J}$ Ophthalmol. 1985;69(6):433-4.

4. Charles ST. Controlled drainage of subretinal and choroidal fluid. Retina. 1985;5(4):233-4.

5. Wilkinson CP, Bradford RH Jr. Complications of draining subretinal fluid. Retina. 1984;4(1):1-4.

6. Jaffe GJ, Brownlow R, Hines J. Modified external needle drainage procedure for rhegmatogenous retinal detachment. Retina. 2003;23(1):80-5.

7. Tornambe PE, Hilton GF. Pneumatic retinopexy and buckling. Arch Ophthalmol. 1990.108(3):318-9. Comment on: Arch Ophthalmol. 1989.107(19):1469-71.

8. Brazitikos PD, Androudi S, Christen WG, Stangos NT. Primary pars plana vitrectomy versus scleral buckle surgery for the treatment of pseudophakic retinal detachment: a randomized clinical trial. Retina. 2005;25(8):957-64.

9. Azad RV, Talwar D, Pai A. Modified needle drainage of subretinal fluid for conventional scleral buckling procedures. Ophthalmic Surg Lasers. 1997;28 (2):165-7.

10. Peyman GA, Charles H, Tawakol ME, Federman J, Ando F. External drainage of subretinal fluid with a contact Nd: YAG laser. Int Ophthalmol. 1987;11(2):77-8.

11. Sonoda Y, Yamakiri K, Sonoda S, Uchino E, Doi N, Sakamoto T. Endoscopy-guided subretinal fluid drainage in vitrectomy for retinal detachment. Ophthalmologica. 2006;220(2):83-6.

12. Yoshida A, Ogasawara H, Jalkh AE, Sanders RJ, McMeel JW, Schepens CL. Retinal detachment after cataract surgery. Surgical results. Ophthalmology. 1992;99(3):460-5.

13. Rosen PH, Wong HC, McLeod D. Indentation microsurgery: internal searching for retinal breaks. Eye. 1989;3(Pt 3):277-81.

14. Girard P, Karpouzas I. Pseudophakic retinal detachment: anatomic and visual results. Graefes Arch Clin Exp Ophthalmol. 1995;233(6):324-30. 